\title{
Paul Ehrlich: pioneer of chemotherapy and cure by arsenic (1854-1915)
}

\section{A LENNOX THORBURN}

SUMMARY Paul Ehrlich's experiments in staining techniques at the end of the nineteenth century resulted in many discoveries which help to form the basis of present research work. Ehrlich's chemotherapy research led to his formulating the arsenic compound, Salvarsan, which was used in the treatment of syphilis during the first half of this century until it was superseded by penicillin.

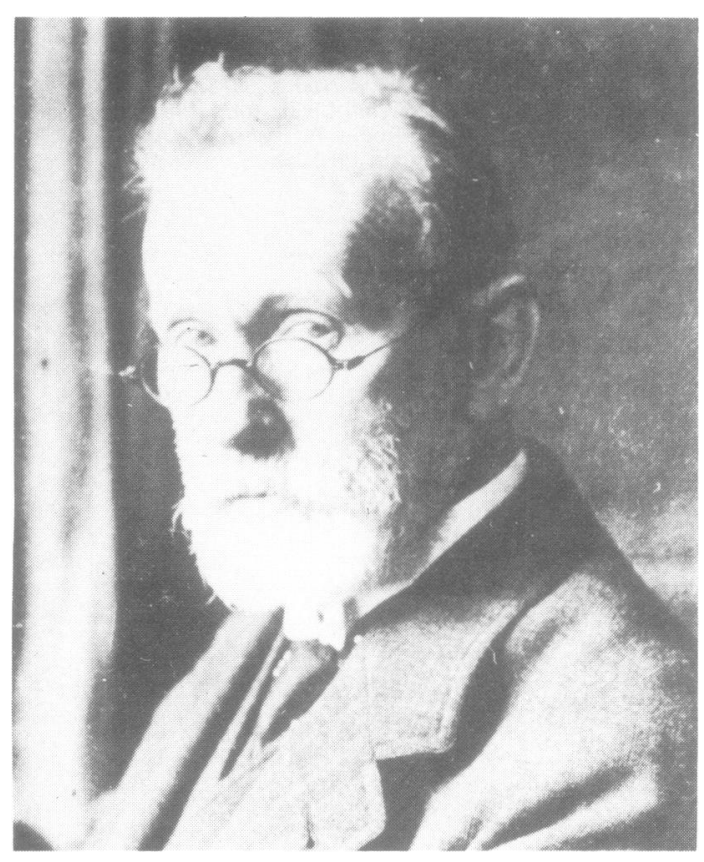

\section{Background}

This remarkable man came of Jewish stock. He was born in Strzelin, Silesia, Germany, schooled at Breslau College, and went to the University there. He later transferred to the newly founded University of Strasbourg, where he entered the medical faculty and met the great Robert Koch.

Ehrlich had an air of alertness and animation and

Address for reprints: Dr A Lennox Thorburn, "Denton Mead", 21 Denton Road, Eastbourne BN20 7SS

Accepted for publication 1 June 1983 was mildly humorous, kindly, and never pompous. He took little exercise, smoking twenty strong cigars daily, and invariably used a cab to and from the laboratory. He read little outside his own scientific range, but was an ardent reader of the Sherlock Holmes stories of Sir Arthur Conan Doyle.

\section{Career}

He completed his studies at Leipzig University with a degree thesis on the value and significance in medicine of staining with aniline dyes. This perceptive work was the groundwork for his side chain theory and showed his essential genius, becoming, in time, the basis of his entire life's work on chemotherapy.

In 1877 after working in a hospital pathology department, he secured an internship at the Charité Hospital, Berlin, where he set up a primitive laboratory in a disused wing. Showing a colleague a pot containing an excised primary chancre, he said "when the microbe causing syphilis is found, I must be prepared". He was to wait until 1905, when Schaudinn and Hoffmann discovered the spirochaete with the new Zeiss ultra powerful lens.

After graduating, he became interested in staining $\frac{7}{O}$ reactions of tissues and discovered mast cells. He later devised a classification of leukaemias which $\tilde{N}$ remains in use to this day, and established the function of bone marrow as a tissue of defence. In 1882, fired with Koch's discovery of the tubercle bacillus, he started experimenting on selected stains which quickly and easily identified the rod shaped organism. This earned him Koch's delight and admiration, and so established a lasting friendship.

Ehrlich married a Prussian lady called Hedwig Pinkus, but shortly afterwards contracted pulmonary tuberculosis. He resigned from his appointment and travelled to Egypt accompanied by his young wife, 
where he made a complete recovery after two years' treatment with Koch's tuberculin. He had resumed intensive experiments on serum antitoxins, when he saw and heard of Von Behring's antitoxin serum for diphtheria. Ehrlich's standardisation of its unit potency has become the accepted basis for diphtheria serum.

For several years Ehrlich experimented extensively with the organic dye, methylene blue, as a better and cheaper substitute for quinine in treating malaria, but it did not succeed clinically. When quinine supplies were cut off in the second world war, however, Bayer laboratories found Ehrlich's work helpful in producing the successful compounds known as Plasmoquin and Atebrin.

Ehrlich became Head of the Royal Institute of Experimental Therapy, Frankfurt, in 1899, and it was here that his career reached its climax. The following year he gave the Croonian Lecture. He selected a brilliant team of researchers, including $\mathbf{C ~ J}$ Browning who was later to become Professor of Bacteriology at the University of Glasgow.

In 1906 Wasserman discovered his reaction for the diagnosis of syphilis, and publicly acknowledged that this was thanks to Ehrlich's pioneer work on haemolysins and the studies of Bordet and Gengou on antibodies. Ehrlich told his workers that, although their past five years' research work on trypanosomiasis had not led to any usable result, they had extended knowledge on protozoa. They now had to make efforts based on Breinl and Thomas' researches at Liverpool University on arsenical organic compounds to find the "silver bullet" (as he called it) against the syphilis spirochaete. These two researchers had produced a pentavalent arsenic compound (Atoxyl) which had been used in treating trypanosomiasis, but had been discontinued as its high arsenic content had caused optic atrophy. The therapeutic problem was how to obtain maximum effect on the parasite with minimum effect on the body tissues. In 1907, Ehrlich produced his six hundred and sixth preparation of an arsenobenzene compound. For some unaccountable reason its potential was overlooked for two years, but later biological work with it on syphilitic rabbits convinced him of its importance. He believed he had found his "silver bullet".

As well as having the best resources of the synthetic chemical industry, Ehrlich had pathologists, biological chemists, bacteriologists, and organic chemists at his call. In retrospect, the scale and magnitude of his operations are quite difficult for us to comprehend. The whole series of trials had taken over four years of patient, painstaking, and devoted scientific investigation by the best brains in Germany. At last the whole world would have a cure for syphilis.
When the chemical firm of Hoechst eventually gained his approval to market Salvarsan (healing arsenic), sometimes called " 606 ", a total of 65,000 free samples were sent to doctors in all parts of the world. At a Congress for Internal Medicine in 1910 at Wiesbaden, he announced the promising results he had achieved with Salvarsan. He was especially fond of telling colleagues of a patient severely crippled with tabes, who was so improved after treatment he could jump on to a moving tramcar. The newspapers carried the good news with banner headlines and international scientific periodicals were equally enthusiastic. Within six months medical men all over the world clamoured for supplies. Ehrlich continually warned them that it might be harmful because of its very powerful action, and urged caution with intravenous injections. The chemical structure of the "silver bullet" was based on $32 \%$ arsenic, and was thus closely related to the poison generally associated with murder cases. Professor Herxheimer, Director of Dermatology at Frankhurt Hospital, also warned colleagues about dosage and, in a thesis based on clinical results, reminded them of reactions after primary injection. Proceedings against Ehrlich on grounds of criminal negligence were started by one Carl Wassman, who slandered Ehrlich publicly and libelled him in newspapers. Ehrlich shrank from defending himself, but Herxheimer brought Wassman to court, where he was sentenced to one year's imprisonment.

After the start of the first world war Ehrlich was under great strain, supervising supplies of Salvarsan and serum on a huge scale for the German army. By 1915 he became physically and mentally exhausted, and died in that year on 20 August from a stroke. He was buried in Frankfurt, the city of which he was a freeman. His obituary in The Times said "He opened new doors to the unknown, and the whole world at this hour is his debtor'. He had received the greatest academic honours, including the Nobel Prize for Medicine, honorary doctorates from the universities of Oxford, Gottingen, and Chicago, the Prize of Honour of German Chemists, gold medals from eleven countries as far apart as Norway and Japan, the Cameron Prize of the University of Edinburgh, and the Prize of Honour at the Lisbon Congress of Medicine.

Salvarsan, and its less toxic derivative Neosalvarsan continued to be widely used in Europe until they were replaced by penicillin in the late 1940s. Their use against yaws carried on even later in the Far

East where penicillin was not easily available and exorbitantly priced.

I thank Scala International of Frankfurt, Bayer Ltd, and the BMA Library for archival assistance. 